\title{
Earnings Management Practices in Indian Companies: A Cross-Sectional Analysis
}

\author{
Mamta Mishra, Amarjeet Kaur Malhotra \\ Ansal University, Gurgaon, India
}

\begin{abstract}
Corporate accounting frauds over the last two decades have caused massive erosion of investor wealth and shattered public confidence in regulators and capital markets. Deliberate manipulation of financial numbers by a company is rarely a one-off event; it is more a culture of widespread earnings management that permeates an organization and eventually leads to a full-blown accounting fraud. This paper looks at earnings management practices in Indian companies and examines the extent of earnings management prevalent across firms of varying market capitalization. The present study examines 130 listed Indian companies during the period of 2013-2015. The findings of this study provide a measure of the quality of financial reporting in India. Modified Jones model (1995) is used to estimate discretionary accruals (DA), which is considered as a proxy for earnings management. The average DA is estimated at $5.6 \%$ of the total assets of the firms, which is comparable to the estimates in other parts of the world (about 1\%-5\% of total assets). A sector-specific analysis reveals presence of higher earnings manipulation in the consumer durable and energy sectors. Large cap companies are found to show a lower level of earnings management as compared to the small-cap firms. The study also finds a dip in the magnitude of DA in 2015, which is the first year of application of the new Companies Act 2013. Subsequent years will reveal the true success of the new Act in enforcing a stricter regime of corporate governance and greater accountability of corporate boards and audit committees. International studies point towards a high degree of correlation between effective audit committees and lower levels of earnings management in companies. Further work in this field from an Indian context will help identify factors that have a constraining effect on earnings management, and ultimately help preserve the sanctity of reported financial numbers.
\end{abstract}

Keywords: India, accounting fraud, discretionary accruals (DA), earnings management, modified Jones model

\section{Introduction}

Accounting frauds over the last two decades have raised a heated debate over financial reporting systems and their inability to detect earnings fabrication. Enron, Xerox, WorldCom and the more recent Satyam scam in India have exposed serious lacunae in financial reporting practices and inadequacy of audit systems. The scams in these companies were not the result of a few accounting misstatements. It was more a culture of widespread earnings management practiced in these firms that eventually led to a full-blown accounting fraud. 
Earnings management can be defined as "the intentional manipulation of financial information by managers, to arrive at a desired level of earnings or profits”. Manipulation of financial information is made possible to a large extent through the flexibility provided by different accounting standards in choosing the accounting method, its application, and timing of events (Ajit, Malik, \& Verma, 2013). It might be worth noting here that earnings management by companies is not a recent evolution. The age-old agency conflict between owners and managers has perhaps been one of the primary originators of earnings management. Managers in a company are often under pressure to report a better than actual performance to the owners. They are further incentivized to indulge in earnings manipulation due to their compensation being tied to the firms' performance.

In recent times, managers have frequently resorted to manage earnings to meet or beat market estimates and analyst expectations. Companies that meet or beat market expectations generally get rewarded through valuation premiums reflected in their stock prices, which eventually translates into a lower cost of capital (Brown \& Caylor, 2005; Goncharov, 2005; Rajpal, 2012). On the contrary, companies that report earnings lower than the market estimate generally see a fall in their stock prices. Apart from the impact on share prices, other incentives that drive earnings management practices include managerial compensation, credit ratings, equity placements, and potential merger and acquisitions (DeAngelo, 1988; Dechow, Sloan, \& Sweeney, 1995; Lundholm, 1999; Hirst, Jackson, \& Koonce, 2003; Easterwood, 1998).

Earnings management negatively affects shareholder wealth and portrays a false picture of the company's actual performance to gullible current and prospective investors, who rely on company financial reports for making investment decisions. Barth, Landsman, and Lang (2008) mentioned that earnings management undermines the quality of accounting. Lower levels of earnings management translate into superior accounting quality. In emerging market economies like India, where there is a high demand for funds by companies, investors need to be assured that they are protected from accounting frauds and deceptive financial reporting. Sustained flow of funds and thriving capital markets require regulators to put in place stringent systems that check and deter financial malpractices and promote a sense of confidence in auditing systems and corporate governance measures. Regulators would also want to ensure that the reported numbers by companies correspond with their real economic values.

Ajit et al. (2013) mentioned that financial regulators are interested in knowing about earnings management practices in firms as it helps to reduce information asymmetry, protect minority shareholders' interests, and improve functioning of capital markets. Financial regulators in the US have attempted to check earnings management practices in firms through the Regulation of Fair Disclosure (RFD) Act passed in 2000 and the Sarbanes-Oxley (SOX) Act in 2002. In India, the Companies Act 2013 has mandated stricter norms for audit committees, auditor independence, and disclosure practices, with a view to ensure transparency in information and curb tendency in managers to manipulate the financial reporting process for securing private gains. Ronen and Yaari (2008) stated that regulatory interventions result in lower earnings management by firms, as was noted through the passage of RFD and SOX in the US.

The findings of this study are likely to help regulators in India scrutinize the functioning of auditors, board of directors, and audit committees, who hold responsibility for sanctity of the financial reporting process. The Companies Act 2013 recognizes this responsibility and has, through new provisions, broadened the scope of duties of auditors and audit committees of companies, in particular. 


\section{Literature Review}

Earnings or "net income" is the single most important item in financial statements and in most cases constitutes the key deciding factor for investors. More often than not, companies tend to get weighed down by market expectations of their earnings. Any significant departure of earnings from market estimates can result in adverse consequences for the company's stock price and impair its future fund-raising endeavours. Goel (2012) mentioned that given the emphasis on earnings, company managers are always interested in its reporting and exercise choices for reporting of earnings. Earnings management originates from this intervention of managers in the financial reporting process.

Thiruvadi and Huang (2011), in their study, attempted to explain the motive for managing earnings through the "agency theory". Conflict between principal (shareholders) and agents of the principal (managers) exists due to differences in goals and appetite towards risk. In order to reduce this conflict, shareholders may incentivize managers by linking their compensation with accounting earnings. This linkage of compensation with earnings has very often proved to be the greatest motivator for managers, to manipulate the earnings by using various techniques of creative accounting.

Goel (2014) mentioned that managers have been provided the flexibility to choose between alternate ways of accounting for transactions as well as choose between options within the same accounting treatment. This flexibility has been designed to allow managers to best adapt to economic circumstances and make a fair portrayal of the economic consequences of transactions. However, managers use this flexibility opportunistically, to "manipulate" the available choices for their personal advantage. The essence of "earnings management" is the ability to manage these choices and arrive at the desired level of earnings. Healy and Wahlen (1999) also defined earnings management as "opportunistic”, where managers act opportunistically and manipulate earnings to secure personal gains.

In recent times, the focus on earnings management has amplified greatly, as is evident from the current research in this area. Prior studies on earnings management confirm its widespread existence. However, much of the existing studies on earnings management have concentrated on the reporting practices in widely held corporations in developed countries, particularly the US. In emerging economies, the literature available is limited, though cross-country evidence points to higher level of earnings intervention in developing countries as compared to their developed counterparts (Bhattacharya, Daouk, \& Welker, 2003; J. Sarkar, S. Sarkar, \& Sen, 2008). Opaque reporting practices and poor earnings quality can adversely affect equity markets in emerging economies, at a time when there is an increased integration of financial markets worldwide. The East Asian crisis in 1997 is an example of how weak governance measures and low accounting disclosure quality exacerbated the collapse of stock markets (Johnson, Boone, Breach, \& Friedman, 2000; Mitton, 2002; Sarkar et al., 2008).

As per Healy and Wahlen (1999, p. 368):

Earnings management occurs when managers use judgment in financial reporting and in structuring transactions to alter financial reports to either mislead some stakeholders about the underlying economic performance of the company or to influence contractual outcomes that depend on reported accounting numbers.

Ajit et al. (2013, p. 8) defined earnings management as "the discretionary use of judgement by managers in financial reporting and in structuring transactions to misinform stakeholders about the underlying economic position and performance of the entity”. 
Though accounting fraud involves a deliberate violation of accounting rules and standards, history would perhaps provide examples that a culture of practising earnings management in some form has eventually been responsible for perpetrating corporate frauds. Corporate accounting scams like Enron, Xerox, Olympus, and Satyam provide ample evidence of how widespread use of earnings management techniques ultimately led to cooking up of accounting books and financial statements (see Table 1).

Table 1

Commonly Used Techniques to Manipulate Earnings

\begin{tabular}{|l|l|}
\hline No. & Techniques \\
\hline 1 & Creating excess provisions and reserves through use of liberal assumptions and estimates \\
\hline 2 & Booking fictitious sales and advance revenues \\
\hline 3 & Restructuring charges \\
\hline 4 & Related party transactions - sales, supplies, loan disbursement \\
\hline 5 & Overstating operating revenues \\
\hline 6 & Aggressive capitalization and extended amortization policies \\
\hline 7 & Overvaluing assets \\
\hline 8 & Undervaluing liabilities \\
\hline 9 & Choice of accounting method \\
\hline 10 & Application of accounting method \\
\hline 11 & Timing asset acquisitions and disposals \\
\hline 12 & Mergers and acquisitions \\
\hline 13 & Cash flow misrepresentation \\
\hline
\end{tabular}

Note. Source: Teoh, Welch, and Wong (1998); Magrath and Weld (2002); Sarkar et al. (2008); Ajit et al. (2013); Verma Gakhar (2013); Goel (2014).

Reflection of capital market expectations on share prices, higher credit ratings that translate into lower borrowing costs and future public offerings, exert pressure on companies to appease investors and consequently manipulate financials, when required (Aharony, Lee, \& Wong, 2000; DuCharme, Malatesta, \& Sefcik, 2001; Gakhar, 2013).

Goel (2012, p. 1) mentioned that an issue for financial analysts, investors, and corporate executives is how to distinguish between earnings manipulation that ultimately proves to be fraudulent and the day-to-day struggles of managers to meet pre-determined targets by using various accounting flexibilities.

As per Ajit et al. (2013), earnings management is made possible by manipulating accruals, where "accruals" refer to the earnings component that does not generate cash flows. Accruals necessitated by business conditions are termed as non-discretionary accruals (NDA) and tend to reverse out in later periods. Most studies on earnings management have focussed on discretionary accruals (DA), which is the portion of accruals created through managers' wilful intervention in the financial reporting process. The present study also considers DA as the proxy for "earnings management".

\section{Measuring Earnings Management}

One of the greatest problems surrounding earnings management is the difficulty involved in detecting manipulation of financial information from publicly available financial statements. Earnings management is neither visible nor transparent. Due to its inherently unobservable nature, all tests designed to measure earnings management can at best be described as close estimates. Healy and Wahlen (1999) and Dechow et al. (1995) attempted to detect earnings management through selection of accounting procedures and changes in 
accounting policies. McMullen and Raghunandan (1996) studied specific accounting transactions to detect the presence of earnings management.

Over the years, a number of models have been developed to estimate earnings management. Most models focus on the use of discretionary or abnormal accruals as a proxy for earnings management (Kothari, Leone, \& Wasley, 2005). Whereas the simpler models measure DA as total accruals, the more sophisticated ones attempt to decompose total accruals into discretionary and non-discretionary components (Dechow et al., 1995). Other commonly used approaches to measure earnings management include earnings restatement, financial reporting fraud, and scrutiny of specific accruals and provisions (Lin \& Hwang, 2010; Ajit et al., 2013).

The earlier simpler models of Healy (1985) and DeAngelo (1986) assumed NDA to be constant over time-periods, and measured the change in total accruals between two periods as a proxy for DA. These models were criticized for their simplistic assumption that NDA remains unchanged between the estimation and event period.

Jennifer Jones (1991) proposed a refinement to these models by relaxing the assumption of constant NDA. Jones model attempts to control for the effects of a company's economic circumstances on NDA. As per Jones, changes in total assets, gross revenue, and gross property plant and equipment (PPE) are the determinants of NDA. However, Jones model was also not free from criticism.

The original Jones model was modified by Dechow et al. (1995), who mentioned that the drawback of the Jones model is in its assumption that sales revenue is entirely unmanaged and hence, a change in sales will result in NDA. Revenues are managed, when managers accrue revenues that are neither earned nor received in cash. This would cause a change in both revenues and receivables. The modified Jones model (1995) factors in the change in receivables that would occur due to change in revenues.

Of all the available models, the modified Jones model (1995) is the most widely used empirical model and provides the most powerful test of earnings management when compared to the Healy model, the DeAngelo model, the Jones model and the industry model (Dechow et al., 1995). This conclusion is also supported by Bartov, Gul, and Tsui (2000). The present study uses the modified Jones model (1995), as was adopted by Ajit et al. (2013) for their empirical investigation of earnings management in Indian companies. The modified Jones model uses a staged-approach to arrive at the DA component and has been described in detail in the research methodology section.

\section{Objectives of the Study}

The main objective of the present study is to examine the presence and extent of earnings management in listed Indian companies of varying market capitalization. The study seeks:

(1) To investigate the presence and magnitude of earnings management in Indian companies through DA estimation;

(2) To explore earnings management practices in different industries;

(3) To examine the pattern of DA (proxy for earnings management) over a three-year time period and between firms of varying market capitalization.

\section{Research Methodology}

\section{Data Collection}

Data used in the study are secondary in nature, and have been sourced from Prowess database maintained by the Center for Monitoring the Indian Economy (CMIE) and annual reports of companies. Financial 
companies were excluded from the study because of different reporting practices, which makes their data incomparable with that of non-financial companies.

Quality and presentation of financial data tends to vary over time. In order to conduct empirical analysis on comparable panel data, period covered in the study is three years, ranging from 2013 to 2015.

\section{Sample Selection}

Earnings management is perceived to be a pervasive phenomenon and is not restricted to specific companies or sectors. Prior studies hint towards more aggressive earnings management practices in the smaller companies than the larger ones (Ajit et al., 2013). This study focuses more on the earnings quality in the mid- and small-cap sectors.

The sample universe comprised of companies constituting the BSE Sensex, mid-cap, and small-cap indices (see Table 2). Of these, finance companies and public sector undertakings were eliminated, as they are subject to different regulatory and procedural requirements that render their financial data incomparable with others.

Table 2

\section{Sample Formation}

\begin{tabular}{ll}
\hline & Number \\
\hline Companies constituting the BSE Sensex, BSE mid-cap, and BSE & 779 \\
small-cap indices as on December 10, 2015 & \\
Less: Financial companies and public sector undertakings included & 102 \\
in the above indexes & 667 \\
Final sample universe & 200 \\
Initial sample (drawn from the universe) & 56 \\
Less: Firms with insufficient information to construct all proxy & 14 \\
measures & 130 \\
Firms from industries with less than 10 observations & 20 \\
Final sample used in the study consisting of companies part of: & 53 \\
BSE Sensex & 57 \\
BSE mid-cap index & \\
BSE small-cap index & \\
\hline
\end{tabular}

Based on the product code provided to each firm in the Prowess database, the sample was classified into 10 different industry groups.

\section{Modified Jones Model}

The performance adjusted (modified) Jones model (1995) was used to measure DA. DA is considered as a proxy for earnings management. Total accruals (TAC), which represent the gap between the reported operating income and operating cash flows of a company, are calculated using the cash flow approach, where:

$$
\text { TAC = Operating Income }- \text { Operating Cash Flow }
$$

TAC is then decomposed into NDA and DA, using the cross-sectional modified Jones model (1995). To adjust for differences in firm size, all variables in Equation (2) are scaled by the total assets at the end of year $t$-1. This also reduces the problem of heteroskedasticity in the regression residuals (Teoh et al., 1998; Kothari et al., 2005):

$$
\frac{T A C_{i j, t}}{T A_{i j, t-1}}=\alpha_{i, t}\left[\frac{1}{T A_{i j, t-1}}\right]+\beta_{i, t}\left[\frac{\Delta R E V_{i j, t}-\Delta R E C_{i j, t}}{T A_{i j, t-1}}\right]+\gamma_{i, t}\left[\frac{P P E_{i j, t}}{T A_{i j, t-1}}\right]+\varepsilon_{i j, t}
$$


where:

$T A C_{i j, t}=$ Total accruals for firm $i$ in industry $j$ in year $t$;

$T A_{i j, t-1}=$ Total assets for firm $i$ in industry $j$ at the end of year $t-1$;

$\Delta R E V_{i j, t}=$ Change in sales for firm $i$ in industry $j$ between years $t-1$ and $t$;

$\triangle R E C_{i j, t}=$ Change in receivables for firm $i$ in industry $j$ between years $t-1$ and $t$;

$P P E_{i j, t}=$ Gross property, plant, and equipment for firm $i$ in industry $j$ in year $t$;

$\alpha_{i}, \beta_{i}, \gamma_{i}=$ Industry-specific estimated coefficients for year $t$;

$\varepsilon_{i}=$ Error term.

The coefficients for Equation (2) $\alpha_{i}, \beta_{i}, \gamma_{i}$ are estimated for each year and each industry using cross-sectional data. The sample data are classified into 10 industry groups, based on their product codes in Prowess database. Consistent with prior research and to ensure representative coefficient estimates, it is required that a minimum of 10 firms listed on the Bombay Stock Exchange exist for each industry in each year (Klein, 2002; Abdul Rahman \& Haneem Mohamed Ali, 2006; Sarkar et al., 2008). Firms belonging to industries with less than ten-year observations are excluded from the study.

The estimated coefficient values $\left(\hat{\alpha}_{i}, \hat{\beta}_{i}, \hat{\gamma}_{i}\right)$ for each industry in each year are fitted in Equation (2) to arrive at NDA.

DA is then calculated using Equation (3) as:

$$
D A=\frac{T A C_{i j, t}}{T A_{i j, t-1}}-\left[\hat{\alpha}_{i, t}\left[\frac{1}{T A_{i j, t-1}}\right]+\hat{\beta}_{i, t}\left[\frac{\Delta R E V_{i j, t}-\Delta R E C_{i j, t}}{T A_{i j, t-1}}\right]+\hat{\gamma}_{i, t}\left[\frac{P P E_{i j, t}}{T A_{i j, t-1}}\right]\right]
$$

Consistent with existing literature in this field, we consider DA as a percentage of total assets to be a proxy for the extent of earnings management prevalent in firms. Positive DAs indicate income-increasing manipulations, while negative DAs are for income-decreasing manipulations. Negative DAs suggest that earnings management can also be in the downward direction.

\section{Empirical Results}

This section presents the results of the empirical analysis conducted above using the modified Jones model (1995). The existing literature on earnings management in Indian companies is rather limited, and has mostly concentrated on the practice of earnings management prevalent in banks and large corporates (Shen \& Chih, 2005; Chipalkatti \& Rishi, 2007; Sarkar et al., 2008; Rudra \& Bhattacharjee, 2012). A recent study on a larger scale by Ajit et al. (2013) attempted to examine the extent of earnings management in listed Indian companies during the period of 2008-2011. They found that the average earnings management in Indian corporate sector is comparable to the estimates in the US, Europe, and elsewhere in the world.

The present study stands distinguished from the previous work done in this field in the Indian context, in as much it examines the prevalence and extent of earnings management in the mid-cap and small-cap sectors as opposed to being restricted to the large firms only. Of the 390 firm-year observations in the study, 330 pertain to firms in the BSE mid-cap and small-cap indices. The study is also the first to focus on the level of earnings management in the year 2015, which is the first year after enactment of the new Companies Act 2013, along with its stringent provisions for corporate governance.

Table 3 shows the descriptive statistics of DA estimates for the sample companies during the period of 2013-2015. The average DA is estimated at 5.6\% of the average total assets of about Rs. 152,558 million during 
the period of 2013-2015. The variance in the magnitude of DA is also significant, as evidenced by the maximum and minimum values.

Table 3

Descriptive Statistics

\begin{tabular}{lll}
\hline & DA & $\begin{array}{l}\text { Total assets } \\
\text { (Rs. in Mn) }\end{array}$ \\
\hline Mean & 0.056 & $152,558.03$ \\
Maximum & 0.580 & $4,332,000$ \\
Minimum & -0.403 & 11.70 \\
Standard deviation & 0.065 & $455,407.81$ \\
Kurtosis & 8.853 & 36.266 \\
Skewness & 0.443 & 5.471 \\
Observations & 390 & 390 \\
\hline
\end{tabular}

Table 4 shows the level of earnings management across firms of varying market capitalization. Large firms (constituting the BSE Sensex) have the lowest magnitude of DA (1.2\% of total assets), whereas it is the highest for firms part of the BSE small-cap index (7.4\% of total assets). The reasons for this could be attributed to greater public interest, wider disclosure norms, and applicability of stricter corporate governance measures to the large firms as compared to firms' part of the mid-cap and small-cap indices. These findings are also supported by the risk-reward theory that higher is the stock risk, greater is the return that investors demand. Small firms are always considered more risky than the large established stocks, and in return, investor expectation from small stocks is always higher.

Table 4

Market Cap and Average DA

\begin{tabular}{lllc}
\hline Firm category & Market cap range (Rs. in Mn) & Average DA (\%) & Number of observations \\
\hline Large firms ( BSE Sensex) & $>200,000$ & 1.2 & 60 \\
Mid cap & $12,000-120,000$ & 5.7 & 159 \\
Small cap & $2,000-12,000$ & 7.4 & 171 \\
\hline
\end{tabular}

Table 5 shows the level of DA across the three-year study period, i.e., 2013-2015. DA is the lowest in 2015 (4.6\% of total assets). The year 2015 being the first year of application of the Companies Act 2013, it would take at least another year to gauge if the new corporate governance norms have actually been effective in curbing managerial intervention in financial reporting process. This opens up the scope for further research in this area.

Table 5

Average DA During 2013-2015

\begin{tabular}{llll}
\hline & 2013 & 2014 & 2015 \\
\hline Average DA & $6.3 \%$ & $5.8 \%$ & $4.6 \%$ \\
\hline
\end{tabular}

Table 6 reports the extent of earnings management found to be prevalent across different industries in Indian corporate sector. The highest magnitude of DA was recorded in consumer durables and power sectors (9.08\% and $8.64 \%$ of total assets respectively), whereas for the healthcare sector, it was the lowest at $2.89 \%$ of total assets. 
Table 6

Industry-Wise Average DA

\begin{tabular}{llr}
\hline Industry & Average DA (\%) & Size ( Rs. Mn) \\
\hline Auto & 5.06 & 218,493 \\
Technology & 5.60 & 74,689 \\
Communication & 7.09 & 192,531 \\
Healthcare & 2.89 & 48,861 \\
Construction/infrastructure & 4.82 & 193,913 \\
Metals \& mining & 3.16 & 264,252 \\
FMCG & 5.09 & 47,916 \\
Services & 5.66 & 20,809 \\
Consumer durable & 9.08 & 23,235 \\
Energy/power & 8.64 & 469,599 \\
\hline
\end{tabular}

\section{Conclusion}

The study, through the application of modified Jones model (1995), estimates average DA (taken as a proxy for earnings management) across different industries in India during the period of 2013-2015. The results of the study confirm the prevalence of earnings management and its varying magnitudes across different industries. The average DA is estimated at $5.6 \%$ of the total assets of the firms during the study period. Earnings management is found to be a more pervasive phenomenon across small-cap firms than the large-cap well-established companies. A sector-specific analysis reveals presence of higher earnings manipulation in the consumer durable and energy sectors. The level of earnings management shows a dip in 2015, which is the first year of application of the new Companies Act 2013. The subsequent years will reveal whether the enhanced measures of governance, audit and financial reporting ushered in by the new Companies Act have actually been successful in constraining earnings manipulation and ensuring sanctity of the reported numbers.

The findings of this study provide a measure of the quality of financial reporting in India. Large cap companies show a lower level of earnings management as compared to the small-cap firms. This also keeps investors wary of putting their money in the small-cap stocks. However, it is also true that India's biggest accounting fraud materialized in a large and well-know company called Satyam. Enforcement of accounting standards, transparent disclosure norms, and stronger measures of corporate governance can go a long way in protecting investor interest, reducing information asymmetry, and preserving the integrity of financial statements.

The present study opens up the scope for further research in this area. International studies point towards a high degree of correlation between effective audit committees and lower levels of earnings management in companies. Further work in this field from an Indian context will help identify specific factors that tend to curb the tendency in managers to purposefully intervene in the financial reporting process. This can throw up useful insights for regulators, lawmakers, and company boards to evaluate the efficacy of corporate boards and enforce stronger governance measures that can restrain earnings management, and ultimately help protect investor interest.

\section{References}

Abdul Rahman, R., \& Haneem Mohamed Ali, F. (2006). Board, audit committee, culture and earnings management: Malaysian evidence. Managerial Auditing Journal, 21(7), 783-804. 
Aharony, J., Lee, C. W. J., \& Wong, T. J. (2000). Financial packaging of IPO firms in China. Journal of Accounting Research, 38(1), 103-126.

Ajit, D., Malik, S., \& Verma, V. K. (2013). Earnings management in India. SEBI DRG Study. Retrieved from http://www.sebi.gov.in/cms/sebi_data/DRG_Study/EMiM.pdf

Barth, M. E., Landsman, W. R., \& Lang, M. H. (2008). International accounting standards and accounting quality. Journal of Accounting Research, 46(3), 467-498.

Bartov, E., Gul, F. A., \& Tsui, J. S. L. (2000). Discretionary-accruals models and audit qualifications. Journal of Accounting and Economics, 30(3), 421-452.

Bhattacharya, U., Daouk, H., \& Welker, M. (2003). The world price of earnings opacity. The Accounting Review, 78(3), 641-678.

Brown, L. D., \& Caylor, M. L. (2005). A temporal analysis of quarterly earnings thresholds: Propensities and valuation consequences. Accounting Review, 80(2), 423-440.

Chipalkatti, N., \& Rishi, M. (2007). Do Indian banks understate their bad loans? The Journal of Developing Areas, 40(2), 75-91.

DeAngelo, L. E. (1986). Accounting numbers as market valuation substitutes: A study of management buyouts of public stockholders. Accounting Review, 61(3), 400-420.

DeAngelo, L. E. (1988). Managerial competition, information costs, and corporate governance: The use of accounting performance measures in proxy contests. Journal of Accounting and Economics, 10(1), 3-36.

Dechow, P. M., Sloan, R. G., \& Sweeney, A. P. (1995). Detecting earnings management. The Accounting Review, 70(2), $193-225$.

DuCharme, L. L., Malatesta, P. H., \& Sefcik, S. E. (2001). Earnings management: IPO valuation and subsequent performance. Journal of Accounting, Auditing \& Finance, 16(4), 369-396.

Easterwood, C. M. (1998). Takeovers and incentives for earnings management: An empirical analysis. Journal of Applied Business Research, 14(1), 29-48.

Goel, S. (2012). Demystifying earnings management through accruals management: An Indian corporate study. Vikalpa, 37(1), 49-56.

Goel, S. (2014). The quality of reported numbers by the management: A case testing of earnings management of corporate India. Journal of Financial Crime, 21(3), 355-376.

Goncharov, I. (2005). Earnings management and its determinants: Closing gaps in empirical accounting research. Peter Lang: International Academic Publishers.

Healy, P. M. (1985). The effect of bonus schemes on accounting decisions. Journal of Accounting and Economics, 7(1-3), 85-107.

Healy, P. M., \& Wahlen, J. M. (1999). A review of the earnings management literature and its implications for standard setting. Accounting Horizons, 13(4), 365-383.

Hirst, D. E., Jackson, K. E., \& Koonce, L. (2003). Improving financial reports by revealing the accuracy of prior estimates. Contemporary Accounting Research, 20(1), 165-193.

Johnson, S., Boone, P., Breach, A., \& Friedman, E. (2000). Corporate governance in the Asian financial crisis. Journal of Financial Economics, 58(1-2), 141-186.

Jones, J. J. (1991). Earnings management during import relief investigations. Journal of Accounting Research, 29(2), 193-228.

Klein, A. (2002). Audit committee, board of director characteristics, and earnings management. Journal of Accounting and Economics, 33(3), 375-400.

Kothari, S. P., Leone, A. J., \& Wasley, C. E. (2005). Performance matched discretionary accrual measures. Journal of Accounting and Economics, 39(1), 163-197.

Lin, J. W., \& Hwang, M. I. (2010). Audit quality, corporate governance, and earnings management: A meta-analysis. International Journal of Auditing, 14(1), 57-77.

Lundholm, R. J. (1999). Reporting on the past: A new approach to improving accounting today. Accounting Horizons, 13(4), 315-322.

Magrath, L., \& Weld, L. G. (2002). Abusive earnings management and early warning signs. The CPA Journal, 72(8), 50-54.

McMullen, D., \& Raghunandan, K. (1996). Audit committees and financial reporting problems. Journal of Accountancy, 182(2), 79-81.

Mitton, T. (2002). A cross-firm analysis of the impact of corporate governance on the East Asian financial crisis. Journal of Financial Economics, 64(2), 215-241.

Rajpal, H. (2012). Independent directors and earnings management - Evidence from India. International Journal of Accounting and Financial Management Research, 2(4), 9-24. 
Ronen, J., \& Yaari, V. (2008). Earnings management: Emerging insights in theory, practice, and research. Springer Series in Accounting Scholarship, Springer.

Rudra, T., \& Bhattacharjee, D. (2012). Does IFRs influence earnings management? Evidence from India. Journal of Management Research, 4(1), 1-13.

Sarkar, J., Sarkar, S., \& Sen, K. (2008). Board of directors and opportunistic earnings management: Evidence from India. Journal of Accounting, Auditing \& Finance, 23(4), 517-551.

Shen, C. H., \& Chih, H. L. (2005). Investor protection, prospect theory, and earnings management: An international comparison of the banking industry. Journal of Banking \& Finance, 29(10), 2675-2697.

Teoh, S. H., Welch, I., \& Wong, T. J. (1998). Earnings management and the long-run market performance of initial public offerings. The Journal of Finance, 53(6), 1935-1974.

Thiruvadi, S., \& Huang, H. W. (2011). Audit committee gender differences and earnings management. Gender in Management: An International Journal, 26(7), 483-498.

Verma Gakhar, D. (2013). Earnings management practices in India: A study of auditor's perception. Journal of Financial Crime, 21(1), 100-110. 